\title{
Rapeseed Products from Double-Low Cultivars as Feed for Dairy Cows: Effects of Long-Term Feeding on Thyroid Function, Fertility and Animal Health
}

\author{
By K.-A. Ahlin, M. Emanuelson and H. Wiktorsson
}

Department of Obstetrics and Gynaecology, Faculty of Veterınary Medicıne, and Department of Animal Nutr1tion and Management, Faculty of Agricultural Sciences, Swedısh University of Agricultural Sciences, Uppsala, Sweden.

\begin{abstract}
Ahlin, K.-Å., M. Emanuelson and H. Wiktorsson: Rapeseed products from double-low cultivars as feed for dairy cows: Effects of long-term feeding on thyroid function, fertility and animal health. Acta vet. scand. 1994, 35, 37-53. - Eighty-five dairy cows of the Swedish Red and White Breed (SRB) were included in a long-term experıment during 3 consecutive lactations. The cows were divided into 3 different dietary groups that received no rapeseed (NR), up to $1.2 \mathrm{~kg}$ dry matter (DM) 00-rapeseed meal plus $0.2 \mathrm{~kg}$ DM full-fat 00-rapeseed (MR), and up to $2.5 \mathrm{~kg}$ DM 00-rapeseed meal plus $0.9 \mathrm{~kg} \mathrm{DM}$ full-fat 00 -rapeseed (HR) per day. No significant differences in culling rates or disease rates were found between the feeding groups at any time during the experiment. The interval from calving to conception among the primiparous cows was longer for the HR-group (125 days) than for the NR-group (100 days). The response to a thyrotroph releasing hormone around 90 days postpartum during the first lactation was significantly higher for the HR-group $(86.7 \mu / \mathrm{L} / \mathrm{h})$ than for the NR-group $(55.2 \mu \mathrm{g} / \mathrm{L} / \mathrm{h})$. This indicates that at the highest level of rapeseed feeding, glucosinolates had a very mild, suppressive influence on thyroid hormone release, apparently compensated for by an increased activity along the hypothalamic-pituitary-thyroid axıs. No significant differences in fertility or thyroid function were found among the pluriparous cows. Durıng 2nd lactation the concentration of serum urea was higher in the NR-group (7.31 $\mathrm{mmol} / \mathrm{L})$ than in the HR-group $(6.83 \mathrm{~mol} / \mathrm{L})$. The effects of independent environmental factors influenced fertility and thyroid function to a much greater extent than the rapeseed feeding. It was concluded that the feeding of rapeseed products from certified double low varieties of $B$. napus to adult darry cows in amounts up to $3 \mathrm{~kg}$ rapeseed meal per cow and day would not have any negative effects on anımal health or fertılity
\end{abstract}

glucosinolates; TRH; TSH; reproduction; metabolic blood profile.

\section{Introduction}

Rapeseed products are a valuable source of protein and energy in rations to dairy cattle. Several reports are in favour of increasing the amounts of rapeseed products in the concentrates (Clandinin \& Robblee 1978, Thomke 1981, Bell 1984). The double low cultivars of Brassica napus oleifera and B. campestris olei- fera contain very low concentrations of antinutritional substances like erucic acid and glucosinolates (00-varieties or LG-varieties or canola).

In spite of the economic advantages by cultivating improved varieties of Brassica oil crops, the usefulness of rapeseed as a feedstuff has been limited. The main reason for 
this are undesirable and toxic effects associated with the level of glucosinolates (Hill 1979, Bell 1984). Glucosinolates from Brassicaceae plants (progoitrin, gluconapin, glucobrassicanapin, napoleiferin, glucobrassicin and neoglucobrassicin) are hydrolysed by the enzyme myrosinase (thioglucoside glucohydrolase; EC 3.2.3.1) at neutral $\mathrm{pH}$. This results in the formation of glucose, $\mathrm{KHSO}_{4}$, goitrogenic compounds, such as 5-vinyl-2-oxazolidinethione (goitrin, OZT, VTO), various isothiocyanates and thiocyanate $\left(\mathrm{SCN}^{-}\right)$. At a low $\mathrm{pH}$, nitriles are also formed, which depress feed intake and growth in addition to having goitrogenic properties (Hill 1979). Low-glucosinolate rapeseed meal (00-RSM) is more palatable than high-glucosinolate rapeseed meal (HG-RSM). However, other toxic substances, such as sinapines and tannins, can cause consumption problems.

Standards for double low cultivars differs between countries, which complicate comparisons between trials. According to Swedish specifications for 00-RSM, erucic acid should not account for more than $2 \%$ of the total fatty acids and 1 gram dry matter (DM) of fatfree meal should not contain more than 40 $\mu \mathrm{mol}$ total glucosinolates. The Canadian (canola-variety) standards are similar for erucic acid but the glucosinolate limit ( $30 \mu \mathrm{mol} / \mathrm{gram}$ fatfree DM), does not include indolyl-glucosinolates. The limit for countries within the European Community is $20 \mu \mathrm{mol}$ glucosinolates per gram air-dried rapeseed, indolyl-glucosinolates included.

Hypothyroidism (overt or subclinical), caused by iodine deficiency, sometimes in combination with goitrogenic agents, has been reported to influence fertility in ruminants. The condition is expressed as increased prevalence of congenital goitre and stillborn calves. In addition, retained placentas and ketonaemia tend to be more common and resistance to infections (endometritis) can be reduced (Wilson 1975).

Most reports on the use of rapeseed products are based on few animals in changeover trials or trials with a short experimental period - often less than 4 months. Consequently, possible long-term negative effects of feeding 00-RSM on metabolism or health have not been shown. The aim of this study was to explore the possibilities of increasing the levels of 00 rapeseed products in dairy cow rations by evaluating the effects on thyroid function, reproduction and animal health.

\section{Materials and methods}

\section{Experimental design}

A total of 95 heifers of the Swedish Red and White Breed (SRB) were introduced during 2 consecutive years. Batch 1 consisted of 47 SRB-heifers calving during 1982-1983, and batch 2 of 48 SRB-heifers calving during 19831984. Each animal was used for a maximum of 3 lactations or until it was culled. Cows were culled if they were accidentally injured, produced less than $4,000 \mathrm{~kg}$ of $4 \%$ fat corrected milk (FCM) per lactation or less than $17 \mathrm{~kg}$ FCM per day, did not conceive within 200 days postpartum or required more than 7 artificial inseminations (AI) to get pregnant. Culled animals were excluded from all calculations concerning fertility. After initial cullings, 85 first calvers were available for more extensive comparisons of different variables (Table1).

Within each batch, the animals were divided into 2 sire groups according to their sire's relative breeding value for milk yield. Within each sire group, the animals were blocked 3 by 3 (blocks 1-16) according to their predicted calving time and were randomly allotted to 3 different dietary groups as applied in the method of stratified and restricted randomisation (Altman 1991). 
Table 1. Number of cows in each of the dietary groups at the beginning of each lactation and experimental year

\begin{tabular}{|c|c|c|c|c|c|c|c|c|}
\hline & & \multicolumn{6}{|c|}{ Experımental year } & \multirow[b]{4}{*}{ Final number } \\
\hline & & \multirow{3}{*}{$\begin{array}{r}1982 / 83 \\
1 \\
\end{array}$} & \multicolumn{2}{|c|}{$1983 / 84$} & \multicolumn{2}{|c|}{$1984 / 85$} & \multirow{3}{*}{$\begin{array}{l}1985 / 86 \\
3 \\
\end{array}$} & \\
\hline \multicolumn{2}{|c|}{ Lactation number } & & 1 & 2 & 2 & 3 & & \\
\hline Batch & Dietary group $^{1}$ & & & & & & & \\
\hline \multirow{3}{*}{1} & NR & 14 & & 12 & & 10 & & 8 \\
\hline & MR & 14 & & 13 & & 12 & & 9 \\
\hline & HR & 13 & & 13 & & 11 & & 7 \\
\hline \multirow{3}{*}{2} & NR & & 15 & & 13 & & 10 & 8 \\
\hline & MR & & 15 & & 12 & & 11 & 10 \\
\hline & HR & & 14 & & 11 & & 9 & 8 \\
\hline
\end{tabular}

${ }^{1}$ No rapeseed (NR), medium level (MR) and high level (HR) of low-glucosınolate rapeseed products.

${ }^{2}$ Number of cows left in each dietary group at the end of the third lactation.

\section{Feeding}

All cows were fed 6.5-7.5 kg DM of grass-red clover silage and 1.2-2.0 kg DM of grass hay (timothy and meadow fescue). Cows in the NR (no rapeseed) group were fed a concentrate mixture in which the protein supplements were mainly based on soybean meal and with tallow as the main fat supply. In group MR (medium rapeseed level) the cows received a maximum of $1.2 \mathrm{~kg} \mathrm{DM}$ extracted $00-R S M$ and $0.2 \mathrm{~kg}$ DM heat-treated, crushed full-fat rapeseed (00-TFR). In group HR (high rapeseed level) the cows were fed up to $2.5 \mathrm{~kg} \mathrm{DM}$ of $00-\mathrm{RSM}$ plus $0.9 \mathrm{~kg}$ DM 00TFR. All diets were isonitrogenous and isocaloric and contained the same levels of fat and minerals. A detailed description of the feeding regimes was presented elsewhere (Emanuelson et al. 1993).

The rapeseed products originated from spring-sown, double-low cultivars of $B$. napus oleifera (Karat or Topas or Hanna). The total glucosinolate content ranged from 17.6 to 31.0 $\mu \mathrm{mol} / \mathrm{g}$ DM in 00-RSM, with a mean of 24.4 $\mu \mathrm{mol} / \mathrm{g} \mathrm{DM}(\mathrm{N}=6)$, and from 4.0 to 15.5 $\mu \mathrm{mol} / \mathrm{g} \mathrm{DM}$ in $00-\mathrm{TFR}$, with a mean of 7.2 $\mu \mathrm{mol} / \mathrm{g} \mathrm{DM}(\mathrm{N}=7)$. By the end of the second year, there had been a decrease in the total glucosinolates in 00-RSM to a level about half that of the first year, and in 00-TFR the original level was halved by the start of the second year.

\section{Fertility}

Data from clinical examinations, analysis of progesterone in whole milk, and heat observations were used. Every animal was examined clinically by rectal palpations starting about 1 week postpartum and once a week thereafter until the first AI. Rectal palpations were performed 6 weeks after the last AI to determine pregnancies.

Samples for radioimmunological analysis (RIA) of progesterone in whole milk were taken twice weekly until a functional corpus luteum (CL) was confirmed. Thereafter, the samples were taken once a week until the first AI. Additional milk samples were taken on the day of AI, 10 and 21 days after AI or if indicated by signs of reproductive problems. The samples were preserved using sodium azide or Bronopol and stored at $4^{\circ} \mathrm{C}$ until as- 
sayed with a commercial progesterone kit (Farmos Diagnostica, Turku, Finland), usually within 1 week after sampling.

The detection limit, calculated as the concentration at $10 \%$ displacement of the labelled ligand, has been reported to $1.6 \mathrm{nmol} / \mathrm{L}$ (Kassa et al. 1986). The standard curve ranged from 5 $\mathrm{nmol} / \mathrm{L}$ over $10,20,30$, and 50 to $100 \mathrm{nmol} / \mathrm{L}$. The intra- and inter-assay coefficients of variation were estimated from the duplicates of the low- and high-control pools in 20 assays. The intra-assay coefficients of variation were $8.4 \%$ for the low pool $(8.8 \pm 1.0 \mathrm{nmol} / \mathrm{L})$ and $3.8 \%$ for the high pool $(56.1 \pm 6.7 \mathrm{nmol} / \mathrm{L})$. The inter-assay coefficients of variation were $8.4 \%$ for the low pool and $11.4 \%$ for the high one.

Every animal was observed 3 times daily, and heat symptoms or external signs of disturbed fertility were recorded. Records from the clinical examinations, progesterone assays, and heat observations were assembled for every animal to create an individual progesterone and fertility profile covering 1 postpartum period. With an established methodology (Larsson et al. 1984), these fertility profiles determined reproductive events and fertility measures during the postpartum period. The following definitions were used:

Uterine involution (UI) was considered complete when the uterine horns were approximately symmetrical and well contained within the pelvic cavity, the uterine wall was soft and pliable, when neither uterine contents nor caruncles could be palpated, and the cranial part of the cervix had a diameter less than or equal to $5 \mathrm{~cm}$.

Ovulation day (OV) was defined as either the day before a post-oestrus bleeding, the day after a fertile AI, 5-10 days before a progesterone level above or equal to $10 \mathrm{nmol} / \mathrm{l}$ whole milk, at least 5 days before the palpation of an active CL $(15 \mathrm{~mm}$ in diameter or larger), or the day after a normal or strong heat (heat code 3 or 4 ).

Oestrus. An animal was regarded to be in oestrus $(\mathrm{H})$ if the total score for all the heat symptoms (including behavioural changes) amounted to heat code 2 or higher. The scale consisted of 5 levels, where $0=$ no oestrus, $1=$ possible oestrus, 2 = weak oestrus, $3=$ normal oestrus and $4=$ strong oestrus.

Ovulatory oestrus. When external signs of heat (at least code 2) were recorded in connection with ovulation this was defined as ovulatory oestrus (OVH).

Normalised reproductive functions (NRF) were considered re-established if $\mathrm{OVH}$ was recorded for the first time after calving on the same day or the day after UI.

Other fertility measures used in the statistical analysis were the interval from calving to first AI (CFI), the interval from calving to conception (CC), and the number of AI per pregnancy (AIP). Any AI repeated within 6 days was excluded from the calculation of AIP. The CC-interval was also calculated with a correction (CCC) when pregnant animals had been accidentally inseminated and later aborted. Such animals were considered to have become pregnant at the time of the first fertile AI. In the same way, a correction was also applied to AIP, denoted AIPC.

\section{Thyroid function}

The thyroid function was evaluated using the thyrotropin releasing hormone (TRH)-test (Laarveld et al. 1981b), performed on around 90 and 300 days after calving. Blood samples were collected from the jugular vein into heparinised Vacutainer tubes $10 \mathrm{~min}$ and immediately before the intravenous administration of $300 \mu \mathrm{g}$ of TRH. Additional blood samples were collected $10,20,30,40,50,60$, and 120 min after the injection. Within $30 \mathrm{~min}$ after collection, the samples were centrifuged at 
$2,100 \mathrm{G}$ for $20 \mathrm{~min}$. The plasma was transferred to plastic tubes, and frozen until assay. All samples were analysed for thyroid stimulating hormone (TSH) using a double antibody RIA-method. The TSH-assay used an antiserum against ovine TSH (NIAMDDanti-oTSH-1) at a final dilution of 1:90,000 and bovine TSH (NIADDK-bTSH-I-1) as a standard (A.F. Parlow, Harbor-UCLA Medical Center, Torrance, CA, USA).

A highly purified bovine TSH (NIADDKbTSH-11) for iodination was used as a tracer. The iodination (carrier-free ${ }^{125} \mathrm{I}$, Amersham International plc, Buckinghamshire, England) was performed by the chloramine-T method (Greenwood et al. 1963) using $16 \mathrm{~g}$ of chloramine-T per $2 \mathrm{~g}$ of protein and an exposure time of $50 \mathrm{~s}$. This is a highly specific RIAsystem for bovine TSH with reported crossreactions of less than $0.2 \%$ with luteinizing hormone (LH), of less than $0.02 \%$ with follicular stimulating hormone (FSH), of less than $0.001 \%$ with prolactin, and of less than $0.07 \%$ with growth hormone (GH) (A.F. Parlow, Harbor-UCLA Medical Center, Torrance, CA, USA). The antiserum generally bound $30 \%$ of the iodinated $\mathrm{bTSH}$, and the standard curve ranged from $0.5 \mathrm{ng}$ to $16 \mathrm{ng}$ of $\mathrm{bTSH}$. The nonspecific binding was less than $4 \%$.

After adding $100 \mu \mathrm{L}$ of antiserum to the samples, the tubes were incubated for $4 \mathrm{~h}$ at room temperature. $100 \mu \mathrm{L}$ of tracer ( ${ }^{125} \mathrm{I}-\mathrm{bTSH}-11$ ) was added, and the tubes incubated overnight at room temperature. The antibody-bound hormone was separated from the free hormone by $2 \mathrm{~mL}$ of a second antibody against rabbit gamma globulin coupled to a solid phase (DASP, Organon, Oss, The Netherlands) and rotated overnight at room temperature. The tubes were rotated at $2,100 \mathrm{G}$ for 3 $5 \mathrm{~min}$, and the precipitate was washed 4 times (first wash with $1 \mathrm{~mL}$, then with $2 \mathrm{~mL}$ ) with a $0.5 \%$ solution of TWEEN 20 (Sigma) in $0.9 \%$ saline before the radioactivity was quantified in a gamma counter (G.D. Searle, Uithoor, The Netherlands). The intra-assay coefficients of variation, calculated from 4 assays, were less than $10 \%$ between $0.5-9.4 \mu \mathrm{g} / \mathrm{L}$. The inter-assay coefficients of variation in 4 assays were $5.8 \%$ for the plasma-pool of $0.3 \pm 0.02$ $\mu \mathrm{g} / \mathrm{L}, 13.7 \%$ for $0.9 \pm 0.1 \mu \mathrm{g} / \mathrm{L}$, and $11.1 \%$ for $2.2 \pm 0.2 \mu \mathrm{g} / \mathrm{L}$ respectively. The minimum average detectable concentration was $0.09 \mu \mathrm{g} / \mathrm{L}$ with the inter-assay coefficients of variation, amounting to $9.3 \%$ in the 4 assays.

To evaluate the TSH-response with a single measurement, the area under the curve (AUC) was calculated for a period of $60 \mathrm{~min}$. Basal levels for each individual were calculated as the arithmetical mean of the 2 ' 0 -samples' before the TRH-injection, which was then subtracted from each value before the AUC was calculated. The AUC represents the quantity $(\mu \mathrm{g})$ of TSH released during $1 \mathrm{~h}(\mu \mathrm{g} / \mathrm{L} / \mathrm{h})$.

\section{Animal health}

The animals were observed by the herdsmen throughout the experimental period, and any signs of disease were recorded. Animals with acute disease were diagnosed and treated by veterinarians. Blood samples were taken from the jugular vein approximately 90 and 300 days after calving (in connection with the TRH-tests).

Serum-TP was determined according to $\mathrm{Pe}$ ters Jr. et al. (1982), serum-urea according to Oltner \& Berglund (1982) and plasma glucose as described by Trinder (1969) with a modification described by Olther \& Berglund (1982). Serum- $\mathrm{P}_{1}$ was determined according to Itaya \& Ui (1966) and modified by Oltner \& Berglund (1982). Serum-Na and serum-K were determined in a flame photometer (Hewett 1974). Serum bile acids were assayed according to Mashige et al. (1981) and serum- 
gamma-glutamyltransferase (EC 2.3.2.2) in a kinetic test (Szasz 1969). After analyses metabolic blood profiles were constructed using a computer.

\section{Statistical analyses}

The effects of the independent factors batch, sire group, block, and dietary group on the reproductive measures, the components of the metabolic blood profile and thyroid function were analysed by a least-squares analysis as applied in the General Linear Model (GLM)procedure (SAS Institute Inc. 1987). The slightly imbalanced design makes the GLMprocedure the method of choice. Because repeated measurements were done on a limited statistical material, each lactation was analysed separately, using the following model:

$$
\mathrm{y}_{1 \mathrm{jkl}}=\mu+\mathrm{a}_{1}+\mathrm{s}_{1 \mathrm{j}}+\mathrm{b}_{\mathrm{ijk}}+\mathrm{d}_{1}+\mathrm{e}_{1 \mathrm{jkl}}
$$

where

$\mu \quad=$ overall mean

$a_{1}=$ ith batch $(i=1,2)$

$\mathrm{s}_{\mathrm{j}} \quad=\mathrm{jth}$ sire group within ith batch $(\mathrm{j}=1,2)$

$b_{\mathrm{ljk}}=$ random effect of kth block within ith batch and jth sire group assumed to be normally distributed with mean $=0$ and variance $=\sigma_{\mathrm{b}}^{2}(\mathrm{k}=1, \ldots 8)$

$\mathrm{d}_{1}=$ lth dietary group $(\mathrm{l}=1,2,3)$

$\mathrm{e}_{1 \mathrm{k} \mathrm{kl}}=$ random residual assumed to be normally distributed with mean $=0$ and variance $=\sigma_{\mathrm{e}}^{2}$

As a consequence of the fluctuation in the non-return-rate (NR) over the year, with a nadir during the darkest winter-months, the model was adjusted taking into account the time of calving. For first calvers the effect of block was already included in the analysis; therefore no other adjustments were made. For older cows the blocks were no longer complete and were therefore replaced by calving season. When analysing the fertility measures and thyroid function, calving seasons were divided up into 3 periods $(1=$ JulySeptember, 2 = October-December, 3 = January-June). In the model for estimating factor effects on components of the blood profile, the calving seasons were divided up into only 2 periods ( 1 = June-November, 2 = DecemberMay) to enable the quality of the silage during $1984 / 85$ to be monitored more closely.

Since age at first calving influences the CCinterval (Strandberg 1986), calving age, broken down into 3 periods $(1=24-26$ months, 2 = 27-29 months, $3=30-33$ months), was included in the model for the primiparous cows. To eliminate the negative influence of outliers and skewed distributions on the assumption of normality, the raw fertility data and the AUC-values of TSH were transformed using natural logarithms and the geometrical least-squares means and the upper and lower borders of a $95 \%$ confidence interval (CI) were transformed back to the original scale.

The distributions of different diseases and reproductive disorders were analysed using the FREQ procedure in SAS with the options Fisher's Exact Test and Mantel-Haenszel Chisquare for trends across the dietary groups. In the analysis the groups were compared separately (NR, MR, HR) and categorically (NR, $M R+H R)$. The frequencies of at least 1 occurrence per individual cow of a particular disease or reproductive disorder, both for separate lactations and for the whole experimental period, were calculated for the dietary groups.

\section{Results}

\section{Glucosinolate content}

The average intake of glucosinolates was 42 mmol per cow and day among the first calvers in the rapeseed-fed groups in batch 1 (Table 
Table 2. Least-squares means (with $95 \%$ confidence interval) for the average dally total amount of glucosinolates consumed during lactation weeks 1-13 (mmol per cow and day).

\begin{tabular}{|c|c|c|c|c|c|c|c|c|}
\hline \multirow[b]{2}{*}{ Batch $^{4}$} & & \multicolumn{7}{|c|}{ Dietary group $^{1}$} \\
\hline & & $\begin{array}{c}\mathrm{MR}+\mathrm{HR}^{2} \\
1\end{array}$ & & $\begin{array}{c}\mathrm{MR}+\mathrm{HR}^{2} \\
2\end{array}$ & & $\begin{array}{l}\mathrm{MR}^{3} \\
1+2\end{array}$ & & $\begin{array}{l}\mathrm{HR}^{3} \\
1+2\end{array}$ \\
\hline \multicolumn{9}{|c|}{ Lactation } \\
\hline 1 & 42 & $(41-44)$ & 44 & $(42-46)$ & 34 & $(32-36)$ & 52 & $(50-55)$ \\
\hline 2 & 55 & $(52-57)$ & 41 & $(38-43)$ & 36 & $(33-38)$ & 60 & $(57-63)$ \\
\hline 3 & 32 & $(29-35)$ & 31 & $(28-34)$ & 23 & $(21-26)$ & 40 & $(37-43)$ \\
\hline
\end{tabular}

1 Medium level (MR), and high level (HR) of low-glucosinolate rapeseed products.

2 Average of dietary groups MR + HR.

3 Average of batch 1 and 2 .

4 Batch 1 was introduced in 1982/83 and batch 2 in 1983/84.

2). This did not differ significantly from the mean consumption in the second batch of first calvers (44 mmol/cow/day). During 1983/84 second calvers in batch 1 consumed the largest average amounts of glucosinolates (55 $\mathrm{mmol} / \mathrm{cow} /$ day) throughout the experimental period. Due to the reduction in glucosinolate content of the rapeseed over the years, third calvers in both batches consumed significantly less $(33 \mathrm{mmol} / \mathrm{cow} /$ day $)$ glucosinolates, in spite of the larger intake of rapeseed products among the multiparous cows.

\section{Culling and animal health}

Initial cullings were made during the first lactation, before any relevant reproductive data could be recorded, ( 3 cows in group NR, 5 cows in group MR, and 2 cows in group HR). The reasons for these exclusions were not related to rapeseed feeding. The most common causes for culling during the experimental period per se were low milk yield (NR $=6$ cows, $\mathrm{MR}=2$ cows, $\mathrm{HR}=1$ cow) and non-pregnancy ( $\mathrm{NR}=4$ cows, $\mathrm{MR}=4$ cows, $\mathrm{HR}=8$ cows $)$. Culling rates did not differ significantly between the dietary groups (Table 1).

There were no significant differences in disease rates or in the occurrence of any repro- ductive disorder between the dietary groups (Table 3), but during the first lactation there were tendencies towards a higher frequency of mastitis in the NR-group and an increased number of acyclic cows in the HR-group.

\section{Fertility and thyroid function}

For first calvers there was no significant main effect of dietary group on any of the fertility traits. Comparisons of least-squares means (LSM) across different levels of the independent variable dietary group revealed, that the UI-interval was longer for the MR-group than for the HR-group (Table 4). The main effect of dietary group was almost significant for the CCC-interval ( $p=0.057)$ and for the TSH-response to the TRH-test $(p=0.051)$, but did not have any effect on the CC-interval $(p=$ 0.11). Both the CC- and CCC-intervals were longer for the HR-group than for the NRgroup, and there was also a tendency for the number of AI per pregnancy to increase with the amount of rapeseed fed (Table 4). In the TRH-test performed at 90 days postpartum the TSH-response was larger for the HRgroup than for the NR-group (Table 4 and Fig. 1). No such differences were seen in the TRHtests made around 300 days after calving. 
Table 3. Numerical distribution of cows with at least 1 instance of a specific disease or reproductive disorder during all 3 lactations.

\begin{tabular}{lrrr}
\hline & \multicolumn{3}{c}{ Dietary group $^{1}$} \\
\cline { 2 - 4 } & NR & MR & HR \\
\hline Diseases. & & & \\
Inappetence & 17 & 20 & 20 \\
Mastitis & 18 & 9 & 14 \\
Diarrhoea & 12 & 16 & 11 \\
Laminitis & 8 & 5 & 7 \\
Ketosis & 8 & 3 & 5 \\
Bloat & 2 & 3 & 6 \\
Udder injury & 1 & - & 6 \\
Foot rot & 2 & 1 & 3 \\
Parturient paresis & 1 & 1 & 1 \\
Reproductive disorders: & & & \\
Acyclic ovaries & 7 & 5 & 13 \\
Cystic ovaries & 9 & 6 & 9 \\
Endometritis & 4 & 5 & 5 \\
Abortion & 4 & 2 & 2 \\
Retained placenta & 2 & 3 & - \\
\hline
\end{tabular}

1 No rapeseed (NR), medium level (MR), and high level (HR) of low-glucosinolate rapeseed products.
For first calvers calving age had a statistically significant main effect on the dependent factors CFI-interval $(p=0.009)$ and CC-interval $(p=0.038)$. Heifers calving at an age of 24-26 months had shorter intervals $(\mathrm{p}<0.01)$ to CFI (70 days; 64-75) and CC (87 days; 77-99) than heifers calving at an age of 27-29 months (CFI $=99$ days; $81-121$ and $C C=142$ days; $103-195)$. The CFI (69 days; 58-82) of the oldest heifers (30-33 months) was similar to that of the youngest heifers, and the oldest heifers did not differ significantly from the other 2 age groups regarding the $\mathrm{CC}$-interval (107 days; 82-141).

For the pluriparous cows dietary group had no main effect on the fertility measures (Table 5) or the results of the TRH-stimulations (Fig. 1) at any time during the lactation. The only difference in LSM occurred during lactation 2 , where cows in the MR-group showed a larger TSH-response than cows in the NRgroup. In second calvers, calving season had

Table 4. Geometrical least-squares means (with 95\% confidence interval) for the reproductive measures (in days) and the TSH-response (in $\mu \mathrm{g} / \mathrm{L} / \mathrm{h}$ ) to the TRH-test during 1st lactation.

\begin{tabular}{|c|c|c|c|c|c|c|}
\hline & \multicolumn{6}{|c|}{ Dietary group ${ }^{1}$} \\
\hline & \multicolumn{2}{|l|}{ NR } & \multicolumn{2}{|l|}{ MR } & \multicolumn{2}{|l|}{ HR } \\
\hline \multicolumn{7}{|l|}{ Reproducttve measures: } \\
\hline Uterıne involution (UI) & $37^{\mathrm{ab}}$ & $(34-42)$ & $41^{a}$ & $(37-46)$ & $36^{\mathrm{b}}$ & $(32-40)$ \\
\hline First ovulation (OV1) & 34 & $(22-50)$ & 33 & $(22-52)$ & 37 & $(24-59)$ \\
\hline First ovulatory oestrus (OVH1) & 60 & (46-77) & 56 & $(42-73)$ & 60 & $(46-78)$ \\
\hline Normal repr. functions (NRF) & 76 & $(63-92)$ & 72 & $(59-88)$ & 81 & $(67-99)$ \\
\hline Calving to first $\mathrm{AI}^{2}$ (CFI) & 74 & $(66-82)$ & 82 & $(73-92)$ & 79 & $(70-89)$ \\
\hline Calving to conception (CC) & $100^{\mathrm{a}}$ & (84-118) & $106^{\mathrm{ab}}$ & $(88-129)$ & $125^{\mathrm{b}}$ & $(103-152)$ \\
\hline Corrected $\mathrm{CC}^{3}(\mathrm{CCC})$ & $94^{\mathrm{a}}$ & $(79-111)$ & $107^{\mathrm{ab}}$ & $(89-129)$ & $123^{b}$ & $(102-149)$ \\
\hline AI per pregnancy (AIP) & 1.68 & $(1.27-2.20)$ & 1.81 & $(1.34-2.44)$ & 2.24 & $(1.65-3.04$ \\
\hline Corrected AIP $^{3}$ (AIPC) & 1.54 & $(1.18-2.01)$ & 1.84 & $(1.37-2.46)$ & 2.16 & $(1.61-2.91)$ \\
\hline \multicolumn{7}{|l|}{ Thyrold function. } \\
\hline TSH-response & $55.2^{\mathrm{a}}$ & $(40.9-74.5)$ & $61.4^{\mathrm{ab}}$ & $(43.1-87.3)$ & $86.7^{\mathrm{b}}$ & $(62.1-121.1)$ \\
\hline
\end{tabular}

ab Least-square means (LSM) within the same row with different superscripts differ significantly $(\mathrm{p}<0.05)$.

1 No rapeseed (NR), medium level (MR), and high level (HR) of low-glucosinolate rapeseed products.

2 Artificial insemination.

3 Refers to correction when a cow was accidentally inseminated during pregnancy and aborted due to this. Fertility was calculated using only the first fertıle insemination. 


\section{Lactation one}

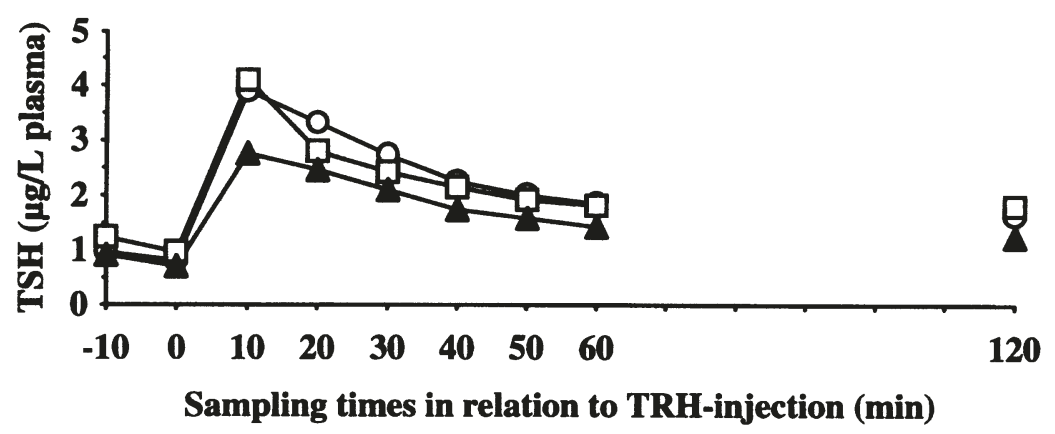

Lactation two

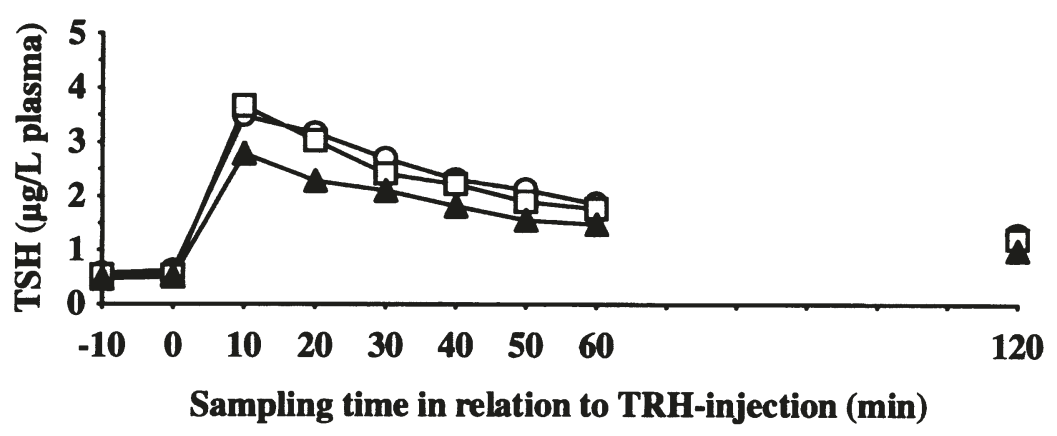

Lactation three

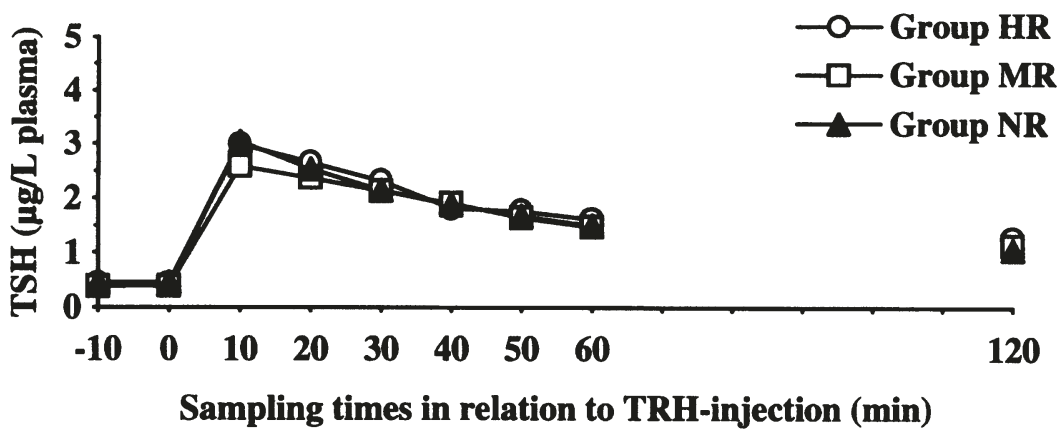

Figure 1. Arithmetical means of the TSH-response after TRH-test around day 90 after calvıng for the different feeding groups during lactation 1-3. 


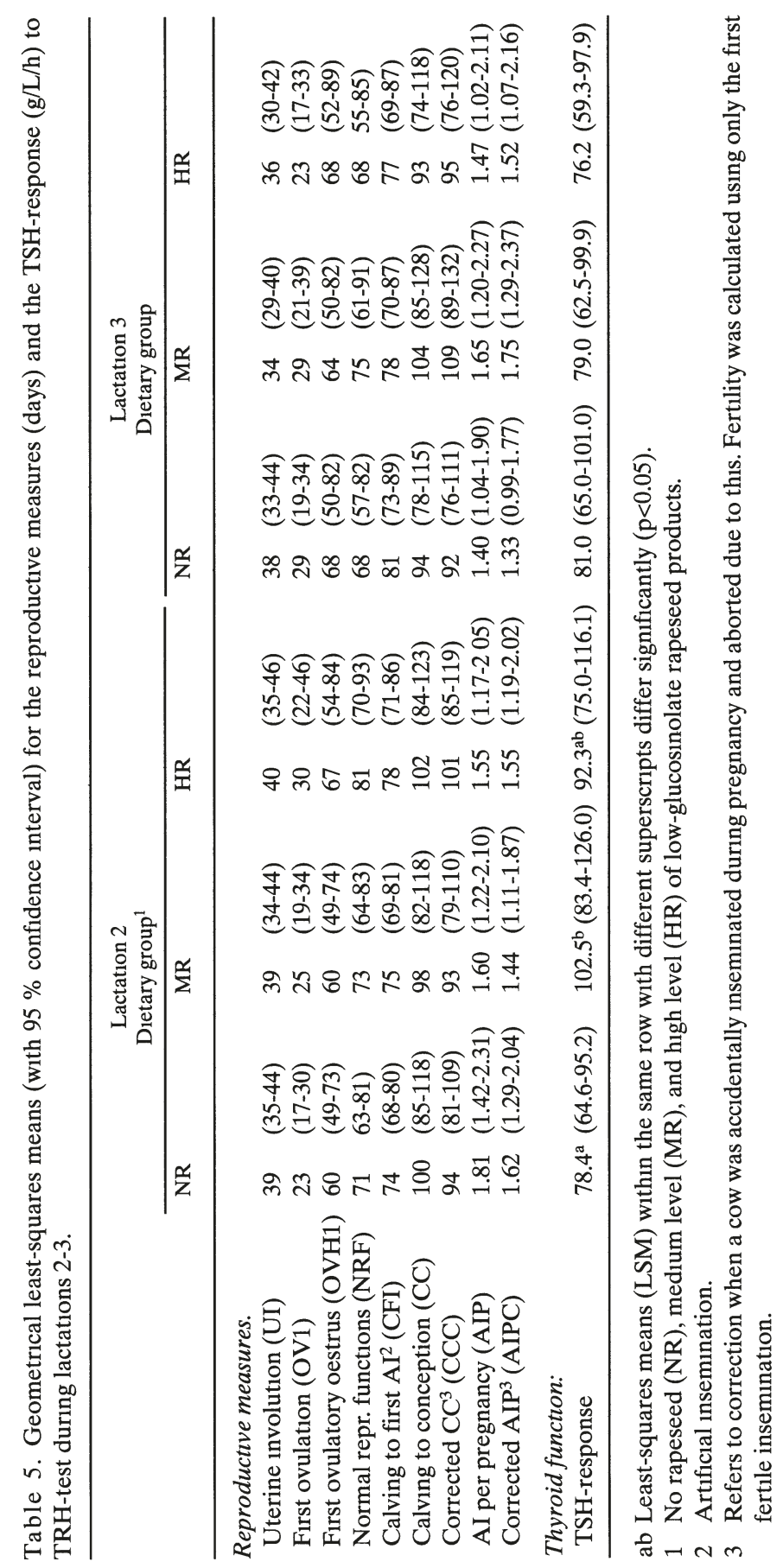


significant main effects on the UI-interval ( $p=$ $0.026)$ and the NRF-interval $(p=0.012)$. Cows calving in July-September completed their UI earlier (34 days; 28-41) than cows calving in October-December (45 days; 41-49), while cows calving in January-June did not differ significantly from cows calving in other seasons (UI = 40 days; 35-46). During July-September and October-December the cows in second lactation resumed NRF earlier (67 days; 55-82 and 70 days; 64-77 respectively) than cows calving during January-June (90 days; 78-103). For the second calvers there was also a significant $(\mathrm{p}<0.001)$ main effect of batch on the TSH-response. Cows calving in 1983/84 showed a much stronger TSH-response $(121.7 \mu \mathrm{g} / \mathrm{L} / \mathrm{h} ; 102.5-144.5)$ compared with cows calving during 1984/85 (67.8 $\mu \mathrm{g} / \mathrm{L} / \mathrm{h}$; 56.8-81.0). For the third calvers batch had a significant main effect on the UI-interval ( $\mathrm{p}=$ 0.012). Cows calving during 1984/85 completed their UI later (41 days; 35-47) than cows calving in 1985/86 (32 days; 28-36).

\section{Metabolic blood profile}

In the first lactation dietary group did not have a significant influence on any of the components of the metabolic blood profile around 90 days postpartum. During the second lactation there was no significant main effect of dietary group on urea, but the NR-group showed higher LSM-levels of urea than the HR-group. During the third lactation the main effect of dietary group on urea level was nearly significant $(p=0.07)$ : Cows in the NRgroup had higher LSM-values of urea than cows in the MR-group. During the whole experiment the urea values in the NR-group tended to be higher than in the rapeseed fed groups.

During lactation 2 batch influenced both urea $(\mathrm{p}=0.037)$ and glucose $(\mathrm{p}=0.013)$ significantly. Cows calving in 1983/84 had lower lev- els of urea $(6.81 \mathrm{mmol} / \mathrm{L} ; 6.53-7.09)$ and higher plasma glucose levels $(3.04 \mathrm{mmol} / \mathrm{L}$; 2.90-3.18) than those in 1984/85 (urea $=7.26$ $\mathrm{mmol} / \mathrm{L} ; 6.98-7.54$ and plasma glucose $=2.80$ $\mathrm{mmol} / \mathrm{L} ; 2.66-2.94)$.

No significant main effects of dietary group were found for any blood constituents sampled around 300 days after calving during lactations 1-2. A significant effect $(p=0.016)$ of dietary group on urea was only found during lactation 3: Cows in the NR-group had higher levels of urea than cows in the MR-group.

\section{Discussion}

During lactations 2-3, levels of serum urea were elevated around 90 days after calving among cows in the NR-group, which was in accordance with the milk urea levels presented elsewhere (Emanuelson 1993). Milk urea is positively correlated with the protein/energy ratio in the diets (Gustafsson 1993), but since there were no differences in the ratio between dietary groups (Emanuelson et al. 1993) this could not explain the different serum urea concentrations in the present study.

Several reports have been published relating either milk urea or plasma urea levels to fertility. Some investigators reported a negative relationship (Ropstad \& Refsdal 1987), while others have found no correlations or a curvilinear relationship (Gustafsson 1993). The tendencies towards impaired fertility for the cows in group HR during lactation 1 could not be explained by the urea level, since there were no differencies between diets. The serum urea values and all the other blood parameters were within the reference ranges. Because of homeostatic mechanisms nutrition-induced alterations in blood parameters may not be detected unless they are pronounced and persistent. 
Neither the culling rate nor the disease rate were influenced by the feeding of rapeseed. Only a few reports have documented significant negative effects on the health from consumption of rapeseed. Ahlström \& Thomke (1978a) found that weight gain was depressed and nostril discharges increased in heifers fed $50 \%$ rapeseed hulls in the concentrates from a high glucosinolate (HG) cultivar. Others reported significantly increased thyroid weights in growing calves fed either HG-RSM or 00RSM (Ekman \& Iwarsson 1974, Ahlström \& Thomke 1978b, Papas et al. 1979). Vincent et al. (1988) fed heifers 2 different levels of HGRSM for 25 -month periods over 2 consecutive years and found histological evidence of goitrogenicity (but no weight change), significantly elevated plasma levels of $\mathrm{SCN}^{-}$, and depressed levels of plasma thyroxin (T4).

In all of the cited experiments young, growing animals were used, and the rapeseed products were mainly from HG varieties. In an experiment where growing bull calves were fed with $10 \%$ and $20 \%$ of $00-\mathrm{RSM}$ in the concentrates (Andersen \& Sørensen 1985), no negative effects on the T4 levels or weights of thyroids or livers were found. The total glucosinolate level in their 00-RSM was less than $12 \mu \mathrm{mol} / \mathrm{g}$ DM. The much higher levels $(31 \mu \mathrm{mol} / \mathrm{g}$ DM of the 00-RSM) given to the first batch of primiparous cows in our study probably explains why fertility and thyroid function were depressed.

The relationship between hypothyroidism in cattle and reproductive disorders has been described in several reports (Wilson 1975). Djurdjević et al. (1982) reported that neonatal calf mortality was $16 \%$ owing to asphyxiation from severe congenital goitres of a parenchymatous, but compensated, euthyroid type. This condition was eliminated by iodine supplementation. Cows which had given birth to calves with goitres had lowered T3- and T4-ti- tres and were regarded as subclinically hypothyroidic. Reddi \& Rajan (1984) studied goats with normal reproductive functions, delayed puberty, postpartum anoestrum and repeat breeding. They found that levels of proteinbound iodine (PBI) in goats with reproductive disorders were significantly lower than in normal goats, with the lowest levels of PBI in the group with postpartal anoestrum.

During the first lactation in our experiment there was a tendency for fertility to be impaired and thyroid function mildly disturbed. This was most likely due to the greater sensitivity to glucosinolates in still growing first calvers as compared with older cows. The 2 batches of first calvers consumed almost the same daily amounts of glucosinolates (Table 2 ), and no relationship between the daily intake of glucosinolates and reproductive capacity could be found.Although cows in batch 1 of lactation 2 were exposed to the highest levels of glucosinolates they showed no signs of infertility. A parallel can be drawn to a study on induced hypothyroidism in small ruminants (Reddi \& Rajan 1985): Thiourea at oral doses of 50 and $100 \mathrm{mg}$ was administered daily to adult female goats and female kids. The ovaries were small, pale, and inactive. The uteri, which were small and infantile, only contained a few mucosal glands which all were inactive. The changes were dose dependent, more severe in young kids than in adults and could be reversed by withdrawing the goitrogenic treatment.

In earlier reports (Lindell 1976, Lindell \& Knutsson 1976), where cows were given up to 1.39 kg HG-RSM, only tendencies toward reduced fertility were observed, such as increased numbers of AI per pregnancy and slightly prolonged CC- and calving-intervals. Ahlstrom (1978) reported a significant $(p<0.05)$ increase in the number of AI per pregnancy in a group of primiparous dairy 
cows given expeller-crushed fines based on a HG-variety of winter rape. These findings contradict those of most studies on the use of HG-RSM or 00-RSM in concentrates for dairy cows, in which no negative effects on fertility were found (Sharma et al. 1977, Papas et al. 1978, Laarveld et al. 1981a, 1981b, Sanchéz \& Claypool 1983). However, the disturbed fertility of the first calvers in our study further indicate that the younger, and still growing, first calvers might have been more sensitive to glucosinolates.

Among the reports from trials using HGRSM as feed for dairy cows are significant depressions of iodide concentration $\left(\left[\mathrm{I}^{-}\right]\right)$and elevations of thiocyanate concentrations ([SCN]) in milk (Iwarsson 1973, Lindell 1976, Laarveld et al. 1981a), increased [ $\left[\mathrm{SCN}^{-}\right]$ (Ahlström 1978), increased [ $\left.\mathrm{SCN}^{-}\right]$and decreased levels of T4 (Vincent et al. 1988) and depressed levels of T4 in serum (Papas et al. 1979). By contrast, when 00-RSM was used $\left[\mathrm{I}^{-}\right]$decreased while $\left[\mathrm{SCN}^{-}\right]$increased (Papas et al. 1978, Laarveld et al. 1981b), and when 25\% 00-RSM was given (Sharma et al. 1977), T4 levels were depressed. The crucial question here is whether these findings represent genuinely hypothyroid conditions or merely indicate a subclinical hypothyroid state, which might even be compensated.

A sufficiently sensitive and reliable test of thyroid function is necessary, especially if there are no significant morphological or histological changes in the thyroid gland. The TSH-response recorded 20 and $60 \mathrm{~min}$ after intravenous administration of $200 \mu \mathrm{g}$ of TRH is regarded as a simple, safe, sensitive, and reliable test of thyroid function in humans in the absence of pituitary or hypothalamic disease (Ormston et al. 1971). In hyperthyroidism or abnormalities in the pituitary or hypothalamus the TRH-test could be accompanied by assays of T3 and T4. The test has also success- fully been applied to dairy cattle to evaluate rapeseed feeding (Laarveld et al. 1981b) and to determine non-toxic levels of iodine supplementation (Convey et al. 1978). Patients with primary, overt hypothyroidism show an exaggerated and prolonged response to the TRH-test. Even the significantly elevated basal TSH-levels are sufficient evidence of an impaired thyroid function in cases of symptomatic hypothyroidism. The TSH-response alone is an extremely sensitive indicator of thyroid function, even in subjects with subclinical hypothyroidism down to the compensated euthyroid state, in which the concentrations of T3 and T4 could fall well within the normal range (Evered 1976).

In the present experiment basal levels of TSH did not differ between the 3 dietary groups. The main effect of dietary group on the TSHresponses was nearly statistically significant in lactation 1, and the largest differences between treatments were found for the 20 - and 30 -min samplings. No prolonged response, characteristic of a more serious hypothyroid condition, was observed. Therefore, it seems most likely that cows in the HR-group suffered from a very mild, subclinical, and probably compensated form of hypothyroidism induced by the depressed $\left[\mathrm{I}^{-}\right]$and elevated $\left[\mathrm{SCN}^{-}\right]$, which also were found in this experiment (Emanuelson et al. 1993). These findings are in line with the results of Laarveld et al. (1981a, 1981b), who found that dietary HGRSM $\quad(76.1 \mu \mathrm{mol}$ glucosinolates per gram DM) contents led to a significant depression of T4 levels and an elevated TSH-response (interpreted as a mild impairment of the thyroid activity). However, no such effects were found when using similar contents of 00-RSM $(11.5 \mu \mathrm{mol} / \mathrm{g} \mathrm{DM})$ resulting in a daily intake of 14-47 mmol glucosinolates.

Although the consumption of glucosinolates was significantly higher among the first batch 
of second calvers in 1983/84 compared with all other cows (Table 2), the fertility of this batch was not significantly reduced. On the other hand, their TSH-response was significantly higher than that of the second batch in 1984/85. In addition, the enhanced TSH-response of the MR-group during the second lactation and the lack of any main effect of dietary group were not associated with any significant reduction in fertility of the rapeseed-fed groups (Table 5). Since the proportion of cows with milk acetone concentrations over $1.00 \mathrm{mmol} / \mathrm{L}$ tended to be larger in the MR-group during the second lactation (Emanuelson 1989), the picture could also be complicated by the reported relationship between ketosis and decreased thyroid activity (Tvelt et al. 1980, Durdevic et al. 1980).

The independent environmental factors, i.e batch, calving age and calving season, had a much greater influence on fertility measures and thyroid function than did dietary group alone. There was no evidence of any significant main effects of dietary group in this study; thus the observed differences in CCinterval and TSH-response to the TRH-test between the NR- and the HR-groups must be biologically less important.

The importance of environmental factors other than the rapeseed dietary component is further reflected in the significant effect of calving season on NRF-intervals, which were prolonged during January-June. For the second batch of second calvers this coincided with a period during which they were intermittently fed silage of low hygienic quality $\left(\mathrm{NH}_{3}-\mathrm{N} 18.5 \%\right.$ of total $\mathrm{N}$; butyric acid $1.1 \%$ of $\mathrm{DM}$ ), which reduced the consumption (Emanuelson 1989). In addition, during this period the first batch of third calvers completed their UI significantly later compared with the second batch of third calvers. The significantly higher concentrations of serum urea and lower titres of plasma glucose in their metabolic blood profiles are also indicative of a suboptimal nutritional state.

A relationship between hypothyroidism and subfertility or infertility should appear when the hypothyroid condition is severe enough to produce a clinically observable change in the thyroid function. However, the reproductive consequences of subclinical, mild forms of hypothyroidism, even with a compensated euthyroid state, and hypothyroidism in adult animals are of dubious importance. In such a situation other environmental and managemental factors in a dairy herd would probably influence fertility to a much greater extent than would goitrogenic compounds at the levels used in this study. Among the potentially important factors are calving age and calving season, the accuracy of heat observations and the timing of $\mathrm{AI}$ in relation to ovulation and calving. Furthermore, the use of carefully adjusted feeding routines to re-establish a positive energy balance as soon as possible after calving, even for the most high yielding dairy cows in the barn, should have a great fertilityenhancing effect.

\section{Conclusions}

Calving age, calving season, and experimental year exerted a much greater influence on both fertility and thyroid function than dietary group. The results indicate that it should be possible to feed rapeseed products from certified double-low varieties of $B$. napus in the concentrates to adult dairy cows in amounts up to $3 \mathrm{~kg}$ rapeseed meal per cow and day without negatively affecting either animal health or fertility. However, it would be wise to avoid feeding rapeseed products in excessive quantities to calves and primiparous cows. 


\section{Acknowledgements}

This project was made possible through financial grants from the Swedish University of Agricultural Sciences (SUAS), the O1lseed Grower's Association (SOC), and the Swedish Farmer's Association for Agricultural Research. The authors are greatly indebted to NIADDK and NHPP, University of Maryland, School of Medicine, USA, and to Dr. A.F. Parlow, Harbor-UCLA Medical Center, Torrance, CA, USA, for providing NIADDK-bTSH-11, NIADDKbTSH-I-1, and NIAMDD-anti-oTSH-1. We also thank Dr Andrze Made and Ms Marı-Anne Carlsson at the Department of Clınical Chemistry, SUAS, for expert technical assistance with the TSH analyses.

\section{References}

Ahlstrom B: By-products from rapeseed protein concentrate (RPC) processing as feedstuffs. I. Fines to dairy cows. In Proceedings of the 5th International Rapeseed Conference, Malmo 1978, Vol. 2, 235-239.

Ahlstrom B, Thomke S: By-products from rapeseed protein concentrate (RPC) processing as feedstuffs. II. Rapeseed hulls to growing heifers. In Proceedings of the 5th International Rapeseed Conference, Malmo 1978a, Vol. 2, 240-243

Ahlstrom B, Thomke S: By-products from rapeseed protein concentrate (RPC) processing as feedstuffs. III. By-product mixture to growing, uncastrated male cattle. In Proceedings of the 5th International Rapeseed Conference, Malmo 1978b, Vol. 2, 244-247.

Andersen $H$ Refsgaard, Sørensen $H$ : Double low rapeseed meal in diets to young bulls. In 'Advances in the production and utılization of cruciferous crops.' Proceedings of a Seminar in the CEC Programme of Research on Plant Protein Improvement, held in Copenhagen, 11-13 September 1984. Martınus Nıhoff/Dr W. Junk Publishers 1985, 208-217.

Altman $D G \cdot$ Practical statistics for medical research. Chapman and Hall, London 1991, 85-90.

Bell JM. Nutrients and toxicants in rapeseed meal: A review. J. Anım Sci. 1984, 58, 996-1010.

Clandının DR, Robblee AR. Evaluation of rapeseed meal and protein for feed use. In Proceedings of the 5th International Rapeseed Conference, Malmo 1978, Vol. 2, 204-212.

Convey EM, Chapin LT, Thomas JW, Leung K, Swanson EW: Serum thyrotropin, thyroxin, and tri-1odothyronıne in dairy cows fed varying amounts of iodine. J. Dairy Sc1. 1978, 61, 771-775.

Djurdjevıć $D_{\jmath}$, Jovanović $M$, Stojlć $V$ : Deficit joda kao limitirajućı faktor u reprodukciji goveda. (A deficiency of iodine as the limiting factor in the reproduction of cattle.). Vet. Glas. 1982, 36, 191-200.

Durdevic D, Stojıc V, Jovanovic MJ, Radakovic N: Concentration of thyroxine, triodothyronine and cortisol in the blood serum of ketotic cows. Acta vet. (Beogr.) 1980, 30, 7-12.

Emanuelson $M$. Rapeseed products of double low cultivars to dairy cows. Effects of long-term feeding and studies on rumen metabolism. Thesis. Department of Animal Nutrition and Management. Report 189. Swedish Unıversity of Agricultural Sciences, Uppsala, Sweden 1989, pp. 182.

Emanuelson $M$, Ahlın $K-\AA$, Wiktorsson $H$ : Rapeseed meal and full fat rapeseed of double low cultıvars to dairy cows. Effects of long-term feeding on animal performances Livest. Prod Sci. 1993, 33, 199-214.

Ekman L, Iwarsson $K^{\cdot}$ The effect of rapeseed meal on the thyroid gland in cattle Fette Seifen Anstrichmittel 1974, 76, p. 368.

Evered $D$. The laboratory investigation of thyroid disease. In 'Diseases of the thyroid.', Pitman Medical, London 1976, 23-46.

Greenwood FG, Hunter WH, Glover JS. The preparation of ${ }^{131} \mathrm{I}$-labelled human growth hormone of high specific radioactivity. Biochem. J. 1963, 89, 114-123.

Gustafsson AH: Acetone and urea concentrations in milk as indicators of the nutritional status and the composition of the diet of dairy cows. Thesis. Department of Anımal Nutrition and Management. Report 222. Swedish University of Agr1cultural Sciences, Uppsala, Sweden 1993, pp.126.

Hewett $C \cdot$ On the causes and effects of variations in the blood profile of Swedish dairy cattle. Acta vet. scand. 1974, Suppl. 50, pp 152.

Hill $R \cdot$ A review of the 'toxic' effects of rapeseed meals with observations on meal from improved varieties. Br. vet. J. 1979, 135, 3-16.

Itaya $K, U_{l} M$ : A new micromethod for the colorimetric determination of inorganıc phosphate. Clin. chim. Acta 1966, 14, 361-366.

Iwarsson $K \cdot$ Rapeseed meal as a protein supplement for dairy cows. I. The influence on certain blood and milk parameters. Acta vet. scand. 1973, 14, 570-594. 
Kassa T, Ahlin $K-\AA$, Larsson $K$, Kindahl $H$ : The effect of mastitis on milk progesterone concentration in dairy cows. Nord. Vet.-Med.1986, 38, 352359.

Laarveld B, Brockman RP, Christensen DA: The effects of Tower and Midas rapeseed meals on milk production and concentrations of goitrogens and ıdide in milk. Can. J. Anım. Sc1. 1981a, 61, 131139.

Laarveld B, Brockman RP, Christensen DA. The goitrogenic potential of Tower and Midas rapeseed meals in dairy cows determined by thyrotropin-releasing hormone test. Can. J. Anim. Sci 1981b, 62, 141-149.

Larsson K, Janson L, Berglund B, Edqvist L-E, Kindahl $H$ : Postpartum reproductive performance in dairy cows. I: Influence of animal, breed and parity. Acta vet. scand. 1984, 25, 445-461.

Lindell $L$ : Rapeseed meal in rations for dairy cows. 2. Comparison on 2 levels of rapeseed meal. Swedish J. agric. Res. 1976, 6, 65-71.

Lindell $L$, Knutsson $P$ - $G$. Rapeseed meal in rations for dairy cows. 1 . Comparison of 3 levels of rapeseed meal. Swedish J. agric. Res. 1976, 6, 55-63.

Mashıge F, Tanaka N, Makı A, Kameı S, Yamanaka $M$ : Direct spectrophotometry of total bile acids in serum. Clin. Chem. 1981, 27, 1352-1356.

Oltner R, Berglund B: Blood levels of haemoglobin, leukocytes, glucose, urea, creatınıne, calcium, magnesium and inorganic phosphorus in dairy calves from birth to 12 weeks of age. Swedish J. agric Res. 1982, 12, 23-28.

Ormston BJ, Garry R, Cryer RJ, Besser GM, Hall R: Thyrotropin-releasing hormone as a thyrordfunction test. Lancet 1971, 10-14.

Papas A, Ingalls JR, Cansfield P: Effects of Tower and 1821 rapeseed meals and Tower gums on milk yield, milk composition and blood parameters of lactating dairy cows. Can. J. Anım. Scı. 1978, 58, 671-679.

Papas A, Ingalls JR, Campbell LD'Studies on the effects of rapeseed meal on thyroid status of cattle, glucosinolate and iodine content of milk and other parameters. J. Nutr. 1979, 109, 1129-1139.

Peters Jr T, Biamonte GT, Doumas BT: Total serum protein by Biuret procedure. In the chapter 'Protein (total protein) in serum, urine, and cerebrospinal fluid; albumin in serum.' in 'Selected methods of clinical chemistry'. Amer. Ass. Clin. Chem. 1982, Vol. 9, 318-320.
Redd NM, Rajan A: The thyrold function in reproductive disorders in goats. Kerala J. vet. Sci. 1984, 15, 105-108.

Reddl NM, Rajan A: Pathology of the female reproductıve organs in experimental hypothyroidism in goats. Kerala J. vet. Sci. 1985, 16, 119-126.

Ropstad E, Refsdal AO Herd reproductive performance related to urea concentration in bulk milk. Acta vet. scand. 1987, 28, 55-63.

Sanchez JM, Claypool DW. Canola meal as a protein supplement in dairy rations. J. Dairy Sci. 1983, 66, 80-85.

SAS Institute Inc: SAS/STAT. Guide for personal computers, version 6 edition., Cary, NC, USA 1987, pp. 1028.

Sharma HR, Ingalls JR, McKirdy JA Effects of feeding a high level of Tower rapeseed meal in dairy rations on feed intake and milk production. Can. J. Anım. Sci. 1977, 57, 653-662.

Strandberg E: Inverkan av muljoeffekter på avkastning, tomperiod och kalvningsintervall i de tre forsta laktationerna hos mjolkkor. (Influence of environmental effects on milk production, calving-conception interval and calving interval during the first 3 lactations in dairy cows.). Report 70, Department of Anımal Breedıng and Genetics, Swedish University of Agricultural Sciences, Uppsala 1986, pp. 44

Szasz $G$. A kinetic photometric method for serumglutamyl transpeptidase. Clin. Chem. 1969, 15, 124-136.

Thomke S: Review of rapeseed meal in animal nutrition: ruminant animals. J. Amer. O1l Chem. Soc. $1981,58,805-810$.

Trinder $P$ : Determination of glucose in blood using glucose oxidase with an alternative oxygen acceptor. Ann. clin. Biochem. 1969, 6, 24-27.

Tvelt B, Halse K, Vlk-Mo L: Thyroideafunksjon og ketose. (Thyroid function and ketosis.) In Husdyrfors $\varnothing$ ksm $\varnothing t e t$, Aktuelt fra Landbruksdepartementets opplysningstjeneste, Oslo, Norway 1980, Nr. 1, 143-148.

Vincent IC, Hill R, Williams $H L \cdot$ Rapeseed meal in the diet of pubertal helfers during early pregnancy. Anim. Prod. 1988, 47, 39-44.

Wilson JG: Hypothyroidism in ruminants with special reference to foetal goitre. Vet. Rec. 1975, 97, 161-164. 


\begin{abstract}
Sammanfattning
Rapsprodukter från dubbellåga sorter ttll mjolkkor: Effekter av långtıdsutfodring på skoldkortelfunktıon, fruktsamhet och djurhalsa.

Under 3 på varandra foljande laktationer studerades 85 mjolkkor av SRB-ras for att utrona eventuella effekter på skoldkortelfunktion, fruktsamhet och djurhalsa av utfodring med varierande mangder rapsprodukter från dubbellåga (00) sorter av Brassica napus. En grupp (NR) utfodrades med ett icke-rapshaltigt koncentrat. En annan grupp (MR) fick maximalt $1.2 \mathrm{~kg}$ torrsubstans (ts) 00-rapsmjol samt upp till $0.2 \mathrm{~kg}$ ts fettrikt 00-rapsfro, medan en tredje grupp (HR) erholl upp till 2,5 kg ts 00-rapsmjol och upp till $0,9 \mathrm{~kg}$ ts fettrikt 00 -rapsfro. Det fanns inga statıstıskt sakerstallda skıllnader mellan utfodrıngsgrupperna med avseende på utgallrings- eller sjukdomsfrekvens. Intervallet från kalvning till draktıghetsgivande insemination (CC) var langre for HR-gruppen (125 dagar) jamfort med NR-gruppen (100 dagar) under forsta laktationen. Svaret vid en TRH-test av skoldkortel-funktionen ca 90 dagar ef-
\end{abstract}

ter kalvnıng var sıgnifikant hogre for HR-gruppen $(86,7 \mu \mathrm{g} / \mathrm{l} / \mathrm{t} \mathrm{tm})$ an for NR-gruppen $(55,2 \mu \mathrm{g} / \mathrm{l} / \mathrm{tm})$ under forsta laktationen. Detta indikerar en mycket svag och sannolikt kompenserad negatıv inverkan på skoldkortelfunktionen av den hogsta rapsgivan. Inga skillnader 1 fruktsamhet forelåg hos de aldre korna. Under andra laktationen observerades dock ett storre TSH-svar 1 MR-gruppen (102,5 $\mu \mathrm{g} / \mathrm{L} / \mathrm{tim})$ jamfort med NR-gruppen $(78,4 \mu \mathrm{g} / \mathrm{L} / \mathrm{tim})$ samt en hogre koncentration av urea 1 plasma 1 NRgruppen $(7,31 \mathrm{mmol} / \mathrm{l})$ an i HR-gruppen $(6,83$ $\mathrm{mmol} / \mathrm{l})$. Effekterna av oberoende miljofaktorer påverkade fruktsamhet och skoldkörtelfunktion i mycket hogre grad an rapsutfodringen. Raps från verifierat dubbellåga sorter av Brassica napus $i$ kraftfodret till vuxna mjolkkor 1 mangder upp till 3 $\mathrm{kg}$ per ko per dag kan inte anses medfora någon okad rısk for negatıva effekter på djurhalsa eller reproduktionsformåga. Eftersom vaxande djur sannolikt ar mera kansliga for hoga intag av glukosinolater an vuxna bor dock maximala givor till forstakalvare undvikas.

(Recelved November 9, 1993; accepted November 19, 1993).

Reprints may be requested from: K.-Å. Ahlın, Department of Obstetrıcs and Gynaecology, Faculty of Veter1nary Medicine, Swedish Unıversity of Agricultural Sciences, P.O. Box 7039, S-750 07 Uppsala, Sweden. 
